\title{
THEORA AND PRACTICE IN THE AREA OF TEACHING AND DEPLOYMENT OF CAD/CAM SYSTEMS
}

\section{Vladimír SOTÁK - Martin KUNÍK - Robert SOTÁK}

\begin{abstract}
Abstrac: In this contribution we focus our attention on the fundamental element of technical literacy mastering CAM/CAD systems. In the first phase of the research, the authors were ascertaining what systems are being used in practice and what are being taught at schools that produce graduates for technical practice. A questionnaire was used as a research tool. Evaluation of the outcomes have not brought only information on what systems are being used in technical practice and at schools, but thanks to them we know what type of knowledge the employers expect from the future graduates in the area of CAD/CAM systems. We all agree that ideally, a graduate should master at least one most frequently used $2 D C A D$ and one $3 D C A D$ system. As to CAM systems, here there is no specific emphasis put on the particular system, rather on the understanding the fundamental philosophy.
\end{abstract}

Key words: CAD/CAM systems, teaching CAD/CAM systems.

\section{TEÓRIA A PRAX V OBLASTI VÝUČBY A VYUŽÍVANIA SYSTÉMOV CAD/CAM}

\begin{abstract}
Abstrakt: V príspevku je venovaná pozornost' dôležitému prvku technickej gramotnosti - práci so systémami CAD/CAM. Autori v rámci prvej etapy výskumu na danú tému zistovali aké systémy sa použivajú v praxi a aké sa vyučujú na školách, ktoré pripravujú absolventov do technickej praxe. Ako nástroj zist'ovania bol použitý dotaznik. Z vyhodnotenia odpovedí nevyplynulo len aké systémy sú použivané v praxi a aké vo výučbe, ale tiež aké majú zamestnávatelia predstavy o vedomostiach budúcich absolventov z oblasti CAD/CAM. V̌setci sa zhodli na tom, že by mal ovládat' aspoñ jeden systém $2 D C A D$ a jeden systém $3 D$ CAD. Tiež sa vo vel'kej miere zhodli na tom, že by malo ist' o systémy najčastejšie použivané vo firmách podl'a prieskumu. Čo sa týka systémov CAM, tu nekladú dôraz na žiaden konkrétny systém, ale na pochopenie myšlienky. Z tejto oblasti neočakávajú ani zvládnutie niektorého systému, stačia im základy.
\end{abstract}

\section{Kl'účové slová: systémy CAD/CAM, výučba systémov CAD/CAM.}

\section{Introduction}

It is a long-term demand to implement needs of practice in the educational process. This trend is being fulfilled at the Department of Technology and Information Technologies (Faculty of Education of Constantine the Philosopher University in Nitra). The research activity of both pedagogues and doctoral students of the department is orientated on the content innovation of curriculum and searching for optimal methods, forms and means to accommodate the theoretical training with the real life. One of such products is the proposal of optimal way of teaching CAD/CAM systems at secondary vocational schools. We are fully aware that we are not alone in this effort. We have studied various springs of inspiration that have become precious and valuable sources of information. Selected pertinent works are mentioned in the list of bibliographical sources. One of the starting points in our research work was to find out what is the real situation in the area of the above-mentioned systems in teaching and in production practice.

\section{Comparison of Used CAD/CAM Systems at Schools and in Companies.}

In the frame of our activity w mapped the usage of $\mathrm{CAD} / \mathrm{CAM}$ systems in engineering companies and at secondary vocational schools orientated on engineering. That was one of the first steps in the sequence of scientific tasks which final effect should be an increment of quality of teaching CAD/CAM systems at the above-mentioned secondary schools. We used a questionnaire to obtain information from 108 companies and 18 schools. As to schools, we tried to find and consequently to address all the secondary schools with specialization on engineering or similar branch; for example, mechatronics, and just 10 questionnaires have been sent back. As to engineering companies, we addressed more than 100 firms. Two of them apologized for being too small to participate in our research and to buy 
particular software and one because of the reason of standing on the edge of bankruptcy. Positive reactions have been sent back in 10 cases. In case of schools that number of the back sent questionnaires represents more than 50 per cent of all addressed institutions, in case of companies it is equal only to less than 10 per cent. Unfortunately, we have to express disappointment over poor interest of firms in cooperation with the aim of increasing quality of education at secondary schools. This attitude is in the clash with publically proclaimed policy and notwithstanding this fact we decided to evaluate the questionnaires.

\section{Evaluation of Questionnaires}

There was a questionnaire with the following questions sent to particular schools and firms: Questions for the firms:

1. What CAD systems do you use in your company? If possible, divide them into $2 \mathrm{D}$ and $3 \mathrm{D}$ groups
2. What CAM systems do you use in your company?

3. What knowledge and skills should a graduate from the secondary engineering school master in the area of CAD/CAM systems?

Questions for the schools:

1. What CAD systems are being taught at your school? If possible, divide them into $2 \mathrm{D}$ and $3 \mathrm{D}$ groups

2. What CAM systems are being taught at your school?

3. How many CAM and CAD lessons per week do you have at your school?

4. How many teachers teach CAD and CAM systems at your school?

5. How many of them attended CAD or CAM training course, or are they graduates from the school where CAD or CAM systems were taught?

From the group of back sent questionnaires we found out following:

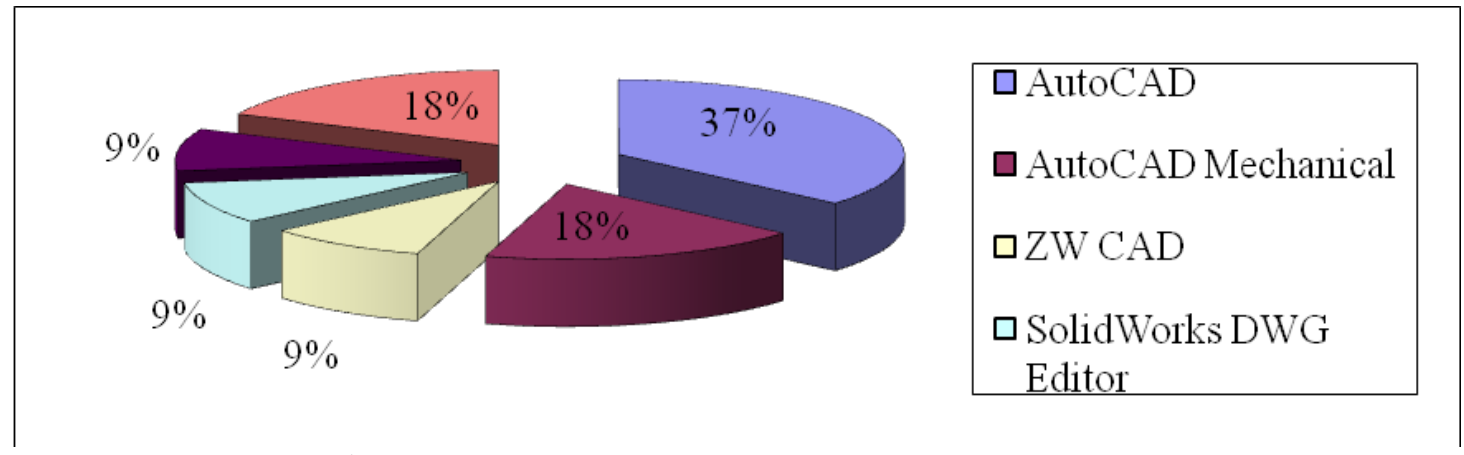

Graph 1 Using of 2D CAD systems in engineering companies

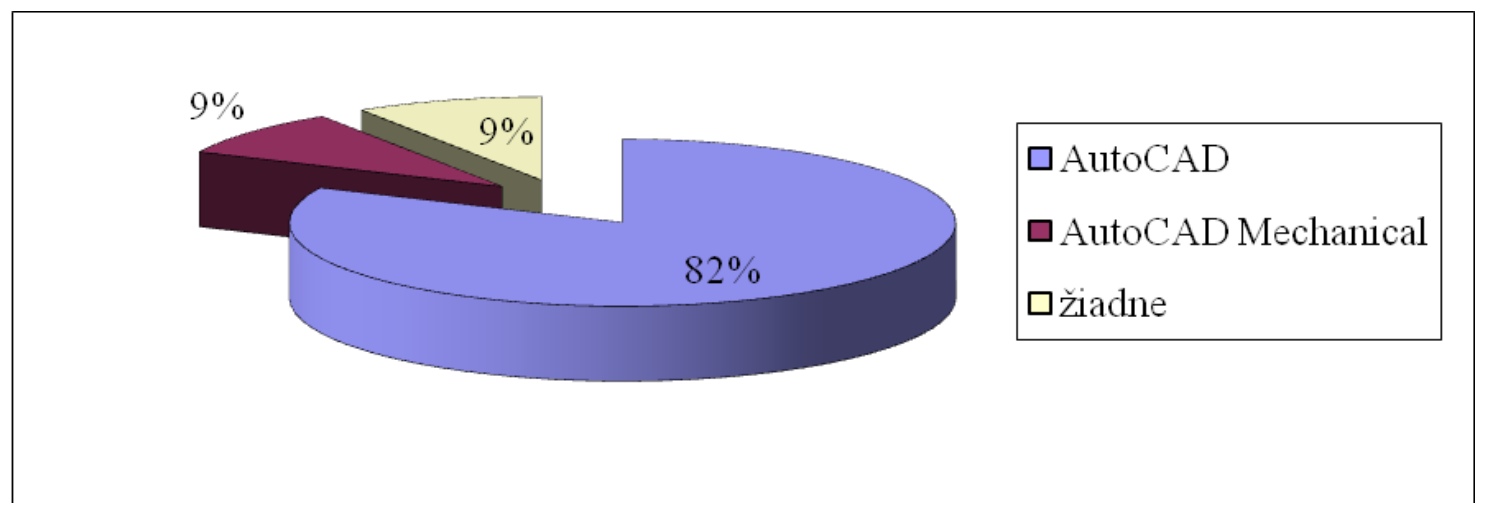

Graph 2 Using of 2D CAD systems in secondary engineering schools

Previous two graphs show the percentage of used 2D CAD systems in companies and schools. As we can see, there are AutoCAD and AutoCAD Mechanical prevailing in the selected companies beside other type of software, meanwhile both above-mentioned systems are the only used systems in selected schools. We see an obvious gap in the school environment and consequently we think and believe that students at the level of secondary vocational school should master one 
more 2D CAD system to better understand differences between particular systems. That is also the way how they can perceive common attributes of CAD systems and in case of using another type of CAD system they are able to adapt easier and more quickly on the new software environment. Next figure shows exact number of schools and firms where 2D CAD systems are used.

Fig. 1 Survey of used 2D CAD systems in firms and schools

\begin{tabular}{|l|l|l|l|l|}
\hline \multirow{2}{*}{ 2D CAD systems } & Firms & \multicolumn{2}{l|}{ Schools } \\
\cline { 2 - 5 } & Number & $\%$ & Number & $\%$ \\
\hline \hline AutoCAD & 4 & 36,36 & 9 & 82,00 \\
\hline AutoCAD Mechanical & 2 & 18,18 & 1 & 9,00 \\
\hline ZW CAD DWG & 1 & 9,09 & 0 & 0 \\
\hline $\begin{array}{l}\text { SolidWorks } \\
\text { Editor }\end{array}$ & 1 & 9,09 & 0 & 0 \\
\hline OneSpace Designer & 1 & 9,09 & 0 & 0 \\
\hline None & 2 & 18,18 & 1 & 9,00 \\
\hline
\end{tabular}

Following graphs show deployment of 3D CAD systems in engineering companies and at secondary engineering schools

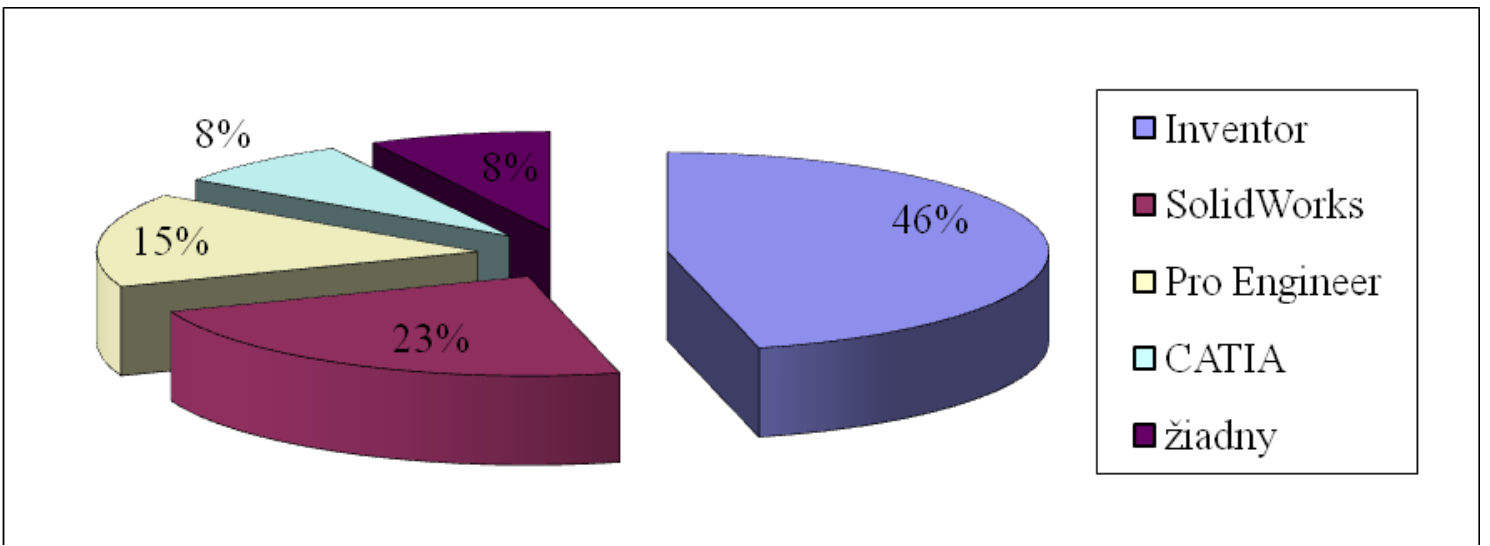

Graph 3 Used 3D CAD systems in engineering companies

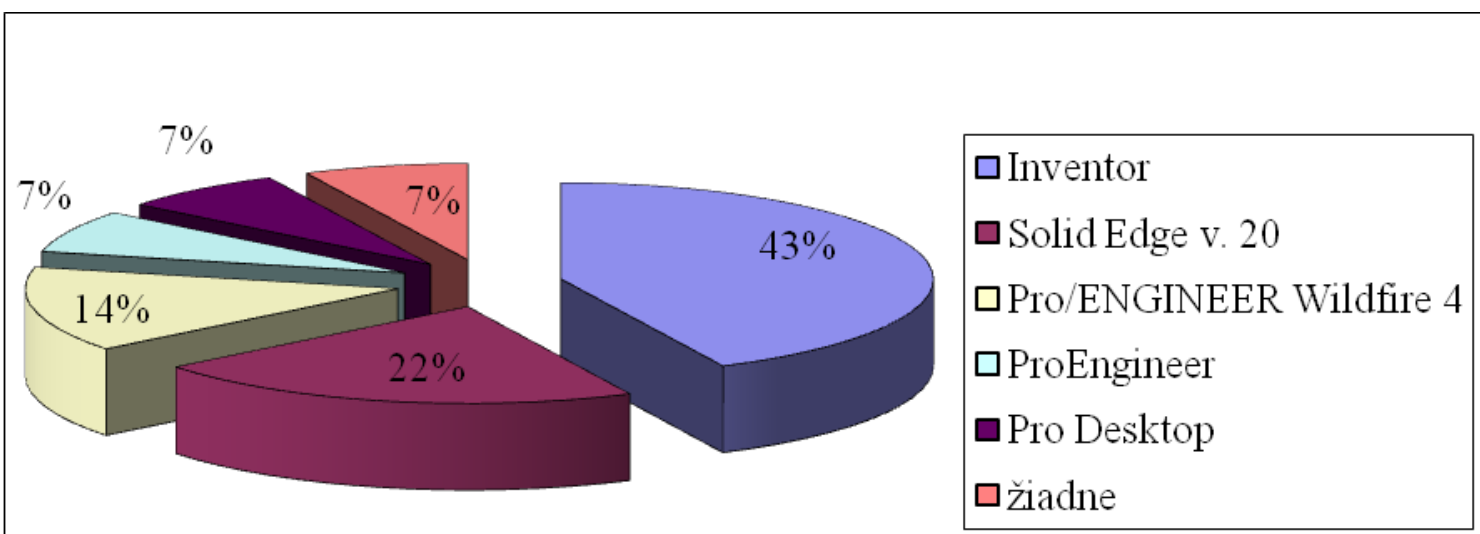

Graph 4 Used 3D CAD systems at secondary engineering schools

In case of 3D CAD systems we see much more of frequent one is Inventor, often used even in used types of software at schools. The most

engineering companies. Paradoxically, Solid 
Edge, the second most used type of software at schools is not used in any of the selected companies. Almost equal percentage represents program ProEngineer.
Next figure shows exact numbers of particular 3D CAD systems in companies and schools.

Fig. 2 Survey of used 3D CAD systems in firms and schools

\begin{tabular}{|l|l|l|l|l|}
\hline \multirow{2}{*}{ 3D CAD systems } & Firms & Schools \\
\cline { 2 - 5 } & Number & $\%$ & Number & $\%$ \\
\hline \hline Inventor & 6 & 46,15 & 6 & 43,00 \\
\hline SolidWorks & 3 & 23,07 & 0 & 0 \\
\hline Pro Engineer & 2 & 15,38 & 1 & 7,00 \\
\hline CATIA & 1 & 7,69 & 0 & 0 \\
\hline Solid Edge v. 20 & 0 & 0 & 3 & 22,00 \\
\hline $\begin{array}{l}\text { Pro/ENGINEER } \\
\text { Wildfire 4 }\end{array}$ & 0 & 0 & 2 & 14,00 \\
\hline Pro Desktop & 0 & 0 & 1 & 7,00 \\
\hline None & 1 & 7,69 & 1 & 7,00 \\
\hline
\end{tabular}

Following graphs show deployment of CAM high price, too little machine park or small systems and obviously they are used only a little. company that can exist without any CAM It is probably caused thanks to more reasons: system.

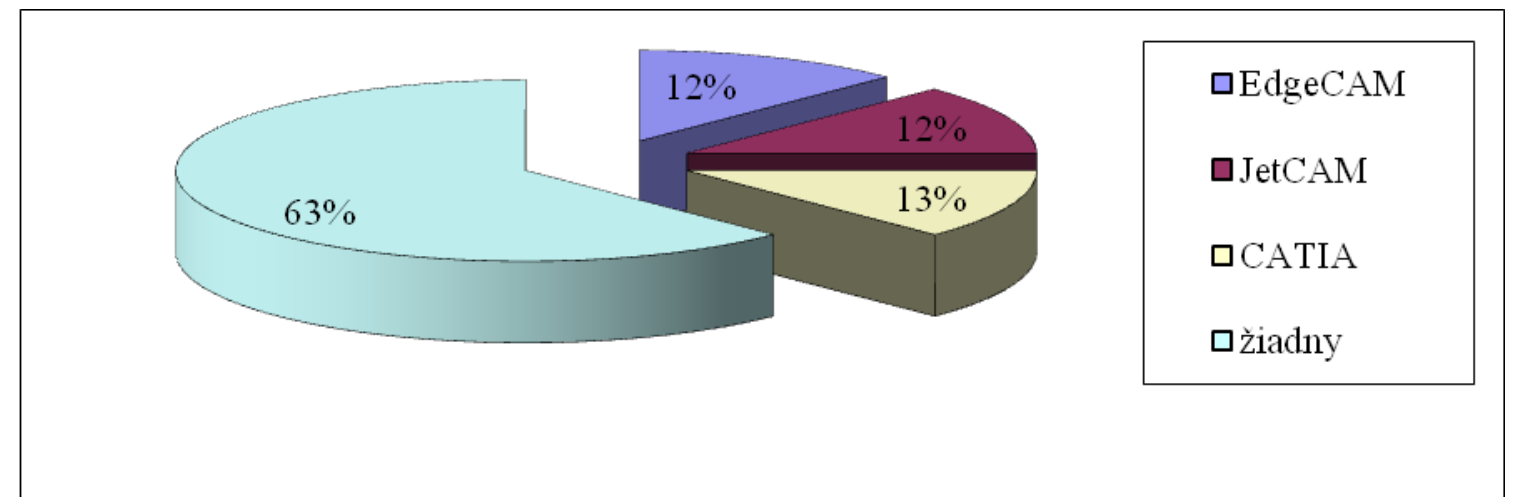

Graph 5 Used CAM systems in engineering companies

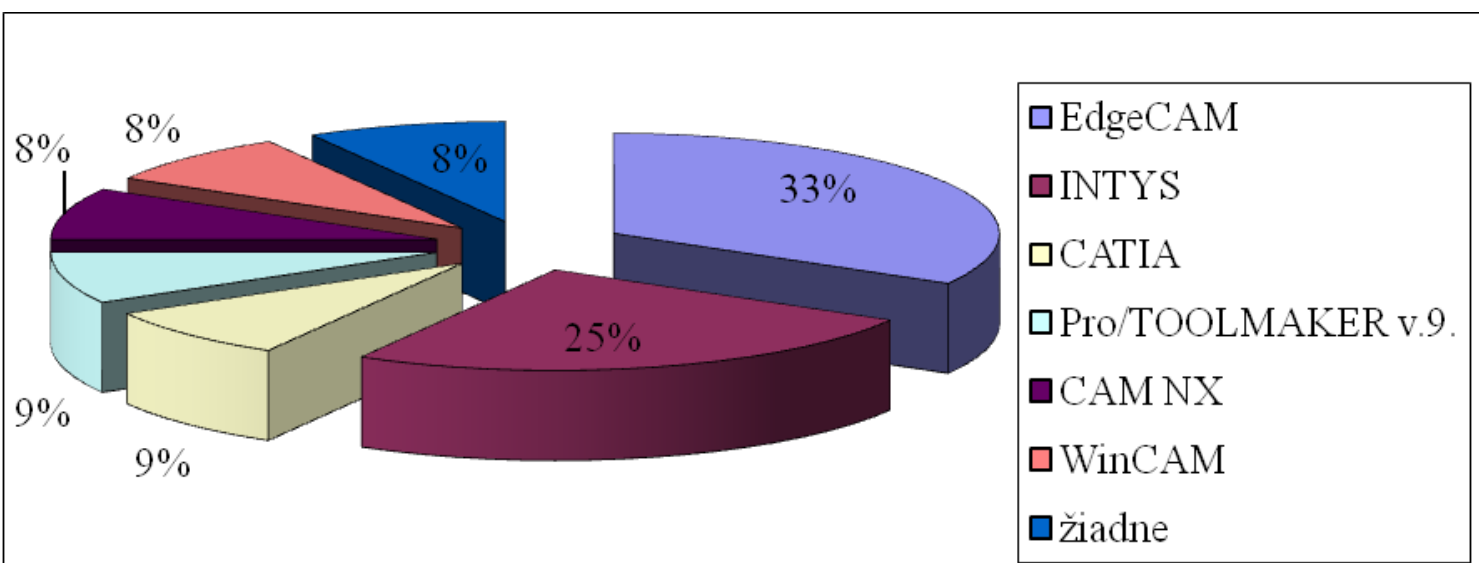

Graph 6 Used CAM systems at secondary engineering schools

The sixth graph shows high diversity of used participating companies. EdgeCAM is used in CAM systems at selected schools and only two of more than a quarter of all addressed schools, and them (EdgeCAM and CATIA) are being used in the same with INTYS. 
Next figure shows exact numbers of particular CAM systems in companies and schools

Fig. 3 Survey of used CAM systems in companies and schools

\begin{tabular}{|l|l|l|l|l|}
\hline \multirow{2}{*}{ CAM systems } & Firms & \multicolumn{2}{l|}{ Schools } \\
\cline { 2 - 5 } & Number & $\%$ & Number & $\%$ \\
\hline \hline EdgeCAM & 1 & 12,5 & 4 & 33,33 \\
\hline INTYS & 1 & 12,5 & 3 & 25,00 \\
\hline CATIA & 1 & 12,5 & 1 & 8,33 \\
\hline JetCAM & 1 & 12,5 & 0 & 0 \\
\hline Pro/TOOLMAKER v.9. & 0 & 0 & 1 & 8,33 \\
\hline CAM NX & 0 & 0 & 1 & 8,33 \\
\hline WinCAM & 0 & 0 & 1 & 8,33 \\
\hline None & 5 & 62,5 & 1 & 8,33 \\
\hline
\end{tabular}

In the last question of the questionnaire for companies the employers were asked to express their opinions on the expected knowledge of graduates in CAD/CAM area. All expressed the same idea that in optimal case a graduate should master at least one 2D CAD and one 3D CAD system, ideally the most frequently used ones. As to CAM systems, there is no specific emphasis put on any particular system, more on the comprehension of the fundamental philosophy what means how CAM system works. Employers do not even expect mastering of any CAM system, they are satisfied when they see that a new employee is able to execute just some basic operations.

The third question of the questionnaire for schools was orientated on how many lessons are allotted for CAD/CAM systems in particular grades. The outcomes show that the average allotment for this subject is 2 lessons per week in the second grade. In other grades there are bigger differences in the allotment and we can say that the only concordance is in the common will to teach these systems.

Other two questions dealt with the teachers and their qualification. We were interested in how many teachers teach CAD/CAM systems at particular schools and how many of them attended special CAM/CAD course or graduated from the school where those systems were taught. Total number of teacher who teach CAD/CAM systems is 30 and 24 of them attended at least one CAD/CAM course or they are graduates from the school where CAD/CAM systems were taught. The ratio of these teachers reaches to 80 per cent.

\section{Conclusion}

Once again we want to remind the fact that only 10 per cent of questionnaires have been sent back from all addressed firms what leads us to the conclusion that there is an enormous lack of interest among employers in the area of education of their future employees and that is why cannot consider this research relevant. Employers should realize that participating in the preparation of students at secondary schools and universities is practically almost free of charge and they have a chance to get a fully-fledged graduate with no necessity of another special training what may save both time and money. It is up to any company to consider opportunities which may help to open the gate of cooperation between the sectors of education and engineering production; however, our critique is directed also to the school sector that more and more prefers theoretical education to the practical one. Employers who reacted on our research have negative experience with the graduates who have problem to project producible components. The crucial problem lies in the connection between theory and practice. Nowadays, we face this problem frequently and that is why we have to focus our attention on it, still it remains unsolved. One loudly expressed idea of an employer concerning the knowledge level of graduates: „On one side, they are capable of mastering software products excellently, but they are only able to project absolutely unproducible outcomes." Employers see the problem in lack of vocational excursions in the course of secondary study. Another problem may be find in unsuitable number of practice lessons, where students should have a chance to design and produce components directly on the turning lathe or milling machine. Employers also call attention to put more emphasis on the so called soft skills (pupil's ardour, good information survey, general interest in engineering, development and new technologies, CAD or CAM skills and so on). To 
reach this desired level we need to motivate and consequently lead our pupils, ideally the sooner the better. Huge responsibility lies on teachers and school institutions themselves. Following comment is addressed to all secondary schools: "Approach of secondary schools involves everything but not marketing behaviour. They must realize that if they want to succeed on the market (in their case it means to attract new students), they must present themselves and also engineering as a whole in a way commercial companies do."

\section{Bibliographic and Webliographic Sources:}

[1] BRYNYCH, M.: Jak mají 3D CAD systémy propracovanou výkresovou dokumentaci. In: IT $C A D, 4 / 2004$. s. $28-31$

[2] BUŠ, L.: Školní software a komerční projekty?. In: IT CAD, 6/2004. s. $42-43$

[3] FABIAN, M.: Požiadavky strojárskej praxe. CA.. gramotnost', jedna zo základných požiadaviek strojárskej praxe. In: IT CAD, 6/2002. s. $32-34$

[4] HIRZ, M. - HARRICH, A. ROSSBACHER, P.: Advanced 3D-CAD Design Methods in Education and Research [online] Publikované 25. 2. 2010. [citované 16. 4. 2011]. Dostupné <http://www.iiisci.org/journal/CV\$/sci/pdfs/GF6 80NA.pdf>

[5] HODAS, S.: CAD I. Návody na cvičenia AutoCAD [online] Publikované 12. 5. 2005. [citované 5. 8. 2007]. Dostupné Z <http://svf.utc.sk/kgd/predmety/Cad_I.html> [6] IBRAHIM, M.: Teaching BIM, what is missing? [online] Publikované 13. 9. 2007. [citované 16. 4. 2011]. Dostupné z
<http://abudhabi.academia.edu/MagdyIbrahim/Pa pers/343073/TEACHING_BIM_WHAT_IS_MIS SING_The_challenge_of_integrating_BIM_base d_CAD_in_todays_architectural_curricula> [7] MARE $\bar{S}$, A. - SENDERSKÂ, K. - FABIAN, M. - VÁCLAV, Š.: CAD systémy $\mathrm{v}$ procesu projektování výrob a jejich implementace $\mathrm{V}$ procesu vzdělávání [online] Publikované 20. 4. 2011. [citované 16. 4. 2011]. Dostupné z <http://www.cad.cz/strojirenstvi/38strojirenstvi/2377-cad-systemy-v-procesuprojektovani-vyrob-a-jejich-implementace-vprocesu-vzdelavani.html>

[8] ŠÍR, J.: CAD/CAM a střední školství ČR. In: IT CAD, 3/2002. s. 15

ŠTULPA, M.: CAD/CAM ve výuce na středních odborných školách. In: IT CAD, 6/2004. s. 40 41

[9] VRŠKOVÝ, R.: CAD systém ako zdroj inovácie profilu učitel'a technickej výchovy [online] Publikované 17. 5. 2007. [citované 16. 4. 2011]. Dostupné z

$<$

http://www.pulib.sk/elpub2/FHPV/Pavelka2/pdf_ doc/vrskovy.pdf>

Doc. Ing. Vladimír Soták, CSc.

Katedra techniky a informačných technológií, PF UKF v Nitre

Dražovská cesta 4 Nitra

Telefón: +42137903038828

E-mail: vsotak@ukf.sk

Web: www.ukf.sk 